\title{
USING PERSONAS IN THE DESIGN PROCESS. TOWARDS THE DEVELOPMENT OF GREEN PRODUCT PERSONALITY FOR IN-CAR USER INTERFACES
}

\author{
Wehr, Franka; Luccarelli, Martin \\ Research Center for Interactive Materials, School of Textiles \& Design, Reutlingen University, \\ Germany
}

\begin{abstract}
The desire to combine advanced user-friendly interfaces with a product personality communicating environmental friendliness to customers poses new challenges for car interior designers, as little research has been carried out in this field to date. In this paper, the creation of three personas aimed at defining key German car users with pro-environmental behaviour is presented. After collecting ethnographic data of potential drivers through literature review, information about generation and Euro car segment led to the definition of three key user groups. The resulting personas were applied to determine the most important interaction points in car interior. Finally, present design cues of eco-friendly product personality developed in the field of automotive design were explored. Our work presents three strategic directions for the design development of future in-car user interfaces named as a) foster multimodal mobility; b) emphasize the interlinkage economy - sustainable driving; and c) highlight new technological developments. The presented results are meant as an impulse for developers to fit the needs of green customers and drivers when designing user-friendly HMI components.
\end{abstract}

Keywords: HMI, User centred design, Sustainability, Industrial design, Green design cues

\section{Contact:}

Wehr, Franka

Reutlingen University

Research Centre for Interactive Materials, School of Textiles \& Design

Germany

franka.wehr@reutlingen-university.de

Cite this article: Wehr, F., Luccarelli, M. (2019) 'Using Personas in the Design Process. Towards the Development of Green Product Personality for In-Car User Interfaces', in Proceedings of the 22nd International Conference on Engineering Design (ICED19), Delft, The Netherlands, 5-8 August 2019. DOI:10.1017/dsi.2019.298 


\section{INTRODUCTION}

Industrial design has two key roles in the development of future in-car user interfaces. Firstly, it is responsible for providing a user-friendly human-machine link that combines optimal physical matching with intuitive information transfer. Secondly, it is in charge of developing a visually appealing product by assigning a specific personality to it. Product personality is defined as the profile of human personality characteristics that people use to describe a specific product variant, i.e. a single physical product, and to discriminate it from others (Govers, 2004; Govers and Schoormans, 2005).

In Germany, $66 \%$ of the respondents involved in a research study showed willingness to pay extra charge for sustainable car components in car interior, however, most of interior car parts made of recyclates and natural materials are currently invisible to customers (Hetterich et al., 2012). Therefore, combining innovative and intuitive interfaces with a product personality that communicates environmental-friendliness to the customer is an appealing goal for German car manufacturers. This desire poses new challenges for car interior designers, as little research has been carried out in this field to date. While research addressing sustainable product physiology (materials and processes) has a solid tradition in technical design, research that addressed product psychology communicating sustainability (usability and personality) is very limited; one likely reason may be the lack of crossfertilization between sustainable design engineering research and human-focused design disciplines like industrial design and interaction design (Wever et al., 2008).

To design the right product features (usability and personality) a user-centred design approach that studies user behaviour, characteristics, needs, and skills to implement solutions that fit those is key. In the case of cars, studying both their customers and drivers is important, since some user groups such as younger generations are increasingly using shared mobility services rather than buying vehicles. On this subject, personas have proven to benefit product design processes (Miaskiewicz and Kozar, 2011). Personas refer to the creation of fictional characters based on data collected from users to represent a consumer type that might interact with a product in a similar way.

Accordingly, the creation of personas aimed at defining key German car drivers with pro-environmental behaviour is presented in this paper. First off, a literature review was carried out to collect ethnographic data. Journal articles, conference proceedings, statistic studies, and project reports from 2004 until 2018 were considered to identify socio-economic characteristics and behaviour of potential users. Next, information about generation type and European car segmentation to create a common shared understanding of driver groups was analysed. The elaboration of user and product information led to the creation of three personas that were used to determine the most important interaction points in car interior. Finally, present design cues of eco-friendly product personality developed in the field of automotive design were explored.

The presented work is expected to help envision future in-car user interaction as well as how human machine interfaces can influence green driver attitude (thoughts) to foster environment conscious consumer behaviour (actions). The contribution of the present study lies in providing insights and impulses to automotive designers and engineers. It outlines future strategic directions for the design of vehicle interiors, thereby serving as a baseline for further investigations towards the development of product usability and personality features of HMI components.

The reminder of this paper is organized as follows. User and product segmentation are introduced in the next sub-section. The development process of personas is highlighted in Section 2, while Section 3 addresses the development of product features, in particular usability in sub-section 3.1 and personality in sub-section 3.2. Finally, the implications of the study are highlighted in Section 4.

\subsection{Background information on user generations and vehicle segmentation}

Among the latest generations, $\mathrm{X}, \mathrm{Y}$, and $\mathrm{Z}$ are of specific interest for this work. Generation $\mathrm{X}$, i.e. the Quintastics, refers to people born between 1965 and 1979. Due to their strong desire for professional success, they are now in the financial position of being able to afford a high standard of living (Mangelsdorf, 2015). Generation Y, i.e. the Millenials, refers to people born between 1980 and 1995. They are the oldest Digital Natives (Bolton et al., 2013) and are at the beginning of their professional and financial careers. Generation Z, i.e. iGeneration, refers to people born after 1996 and is considered to be the generation that had been in contact with the Internet since their youngest childhood (Turner, 2015; Mangelsdorf, 2015). The members of this generation are still at school, on vocational training, or are just starting their professional careers. 
The Commission of the European Communities (1999) classifies vehicles according to weight and size parameters into the segments A-F, J, M and S. The generations are assigned to the car segments from which they could potentially either drive or buy a car according to both their professional and financial status as well as the car prices (International Council on Clean Transportation Europe, 2017). The analysed information about generation type and European car segmentation is used to identify a common shared understanding of three driver groups, i.e. A/B segments for generation $\mathrm{Z}, \mathrm{C} / \mathrm{M} / \mathrm{D}$ segments for generation $\mathrm{Y}$, and $\mathrm{E} / \mathrm{J}$ segments for generation $\mathrm{X}$, Figure 1.

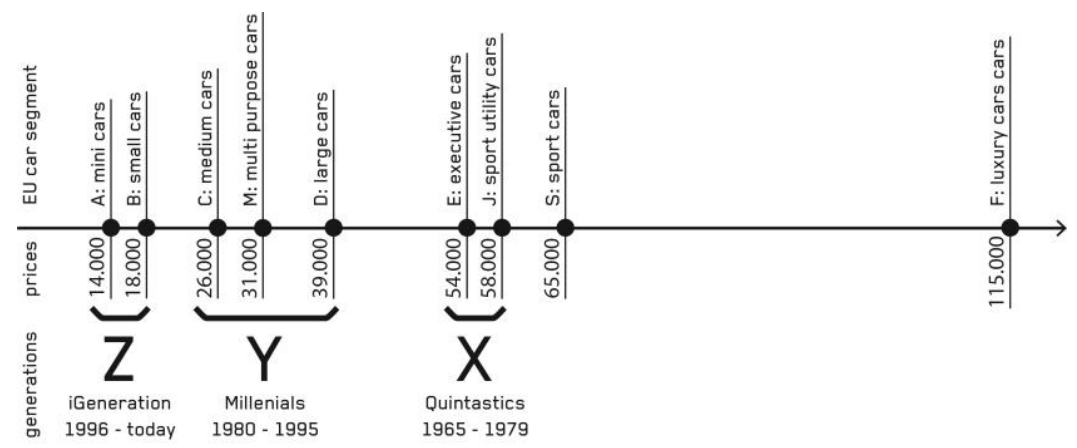

Figure 1. EU car segmentation with average vehicle prices assigned to each generation

\section{SOCIO-ECONOMIC CHARACTERISTICS OF THE CUSTOMERS}

The three personas presented in this section represent socio-economic characteristics and behaviour of each generation, and focus on the respective preferred car segment. The first persona is a member of the iGeneration and stands for the new trends in transportation such as collaborative consumption, connected vehicles, and efficient multimodal networks (Polchow, 2017). A survey conducted in 2015 with 500 respondents aged 18-69 shows that 18-29 year olds in particular display medium to high interest in car sharing (Naumann, 2016). Studies dealing with car sharing and its users indicate that the majority of users are male (BMW et al., 2016; Loose, 2010; Schreier et al., 2015), on average 36 years old (BMW et al., 2016) and have an university entrance qualification (BMW et al., 2016; Kopp, 2015; Schreier et al., 2015). A telephone interview carried out with the German car sharing company DriveNow (Merk, 2018) confirmed the high proportion of male users, but also highlighted that the proportion of female users is consistently growing. Therefore, the female persona Frederike Bäumle was chosen as representative of this group. The second persona belongs to the Millenials and is the buyer of the bestselling car. As representative of the broad masses, Florian Steiner is very keen on economical driving and places great importance in purchasing a car at an unbeatable price-performance ratio (Arbeitsgemeinschaft Verbrauchs- und Medienanalyse, 2017b2). The third persona named Christian Peters is a Quintastic. Due to his economic possibilities and the willingness to pay premium car prices, he is one of the early adopters of new technologies (Naderer and Balzer, 2007). For this persona the symbolic values, i.e. his associations, and the affective motives, i.e. his perceptions, play an important role in car use (Steg, 2005). Florian and Christian are chosen as personas, as 58.8\% of German respondents who are certainly planning to buy a car in the next two years are male (Statista, 2017b). Accordingly, Frederike's driving choices range from A to B segment cars, Florian's car preferences vary between $\mathrm{C}$ and $\mathrm{D}$ segment vehicles, and Christian's car choices are between $\mathrm{E}$ and $\mathrm{J}$ vehicle typologies, Figure 2 .

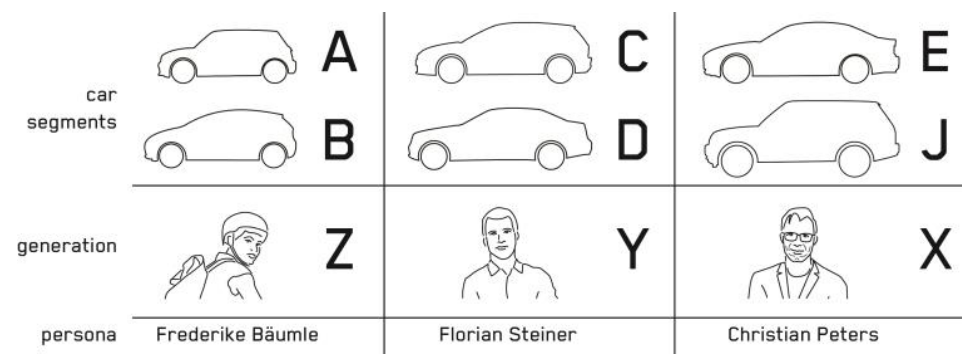

Figure 2. Classification of car segments, generation and personas 


\subsection{Frederike Bäumle - new trends}

She is 21 years old and belongs to Generation Z (Mangelsdorf, 2015). She has been a digital native since birth. Frederike studies and lives in a big city (Shaheen and Cohen, 2013). Besides her studies, she works and has an income of about $1000 €$ net per month (Kambeck et al., 2009). She does not own a car and has no interest in buying one (Bogenberger et al., 2016). Frederike usually travels to university, work and sport by bicycle or public transport. For longer distances or in bad weather she would like to drive a car (Kopp, 2015; Kuhnimhof et al., 2012). That is why she uses her city's car sharing system, and she selects vehicles out of segment A and B.

\subsection{Florian Steiner - mainstream}

He is 31 years old (Köster and Pütz, 2018) and thus assigned to Generation Y. He can be considered a digital native as he spent his entire life in a digital environment (Mangelsdorf, 2015). Florian is a business economist in permanent employment and earns $2500 €$ net per month (Statistisches Bundesamt, 2018). He lives with his girlfriend in the city. Florian Steiner would buy a car from the C or D segments (Statista, 2017a). For him, the most important vehicle features are low fuel consumption, good interior fittings, intuitive operations and high driving comfort (Statista, 2017c). Florian's top priorities are the radio, navigation system, brake assist and cruise control (Statista, 2016).

\subsection{Christian Peters - innovation}

Christian Peters is male, 51 years old and a Generation X representative (Mangelsdorf, 2015; Ford, 2016). At the age of 51 he belongs to the second largest group, the 50- to 59-year-olds, of car buyers (Köster and Pütz, 2018). He lives in a large household with his wife and two children (Choo and Mokhtarian, 2004), a detached house in a small town. As manager of his own company he has an income of over $4000 €$ net per month (Kambeck et al., 2009). For his job he drives daily by car to another city (Choo and Mokhtarian, 2004). For him, a sport utility vehicle (SUV), i.e. J segment, is the best vehicle to drive anywhere. As appealing alternative, he also likes executive sedans belonging to the E segment. Christian is passionate about technology and high-performing vehicles, and his car has to reflect his lifestyle as well as his social status (Adam, 2016).

\section{ANALYSIS OF THE PRODUCT CONTEXT}

The product context is key to understand how the designed product features can cope with user characteristics, the tasks it is carrying out, and the physical and social environment in which the product is used (Hekkert and Dijk, 2001). Therefore, it affects the way basic design requirements such as product function, product usability, and product personality are considered and developed.

In order to successfully combine usability features with personality characteristics, the most important interaction points in car interior (where) are explored for each user group according to driver's attitude and behaviour (why and when) in the next subsection. Subsequently, the determination of an environmentally friendly product personality is explored by analysing alternative fuel vehicles of German car makers.

\subsection{Determination of key interaction points in car interior}

Usability describes the ways in which the product communicates with the user and is made of the ensemble of physical matching and information transfer features. While physical matching addresses motoric functions through bio-metric and bio-mechanical considerations, information transfer deals with sensory and cognitive functions via operation and feedback tasks.

In a previous work (Luccarelli, 2017) car door, centre console, centre tunnel console, crash pad, dashboard, seats, and steering wheel were identified in literature as key car interior components contributing to consumer perception. Among these components, the centre console is of specific interest for the youngest driver group (Frederike Bäumle) to interact with different transport modes. The dashboard has great relevance for the intermediate user group (Florian Steiner) to monitor realtime fuel economy. Finally, the dashboard, centre console, centre tunnel console, crash pad, and steering wheel are key components for the eldest user group (Christian Peters) as they are linked to symbolic values and affective motives, Figure 3. 


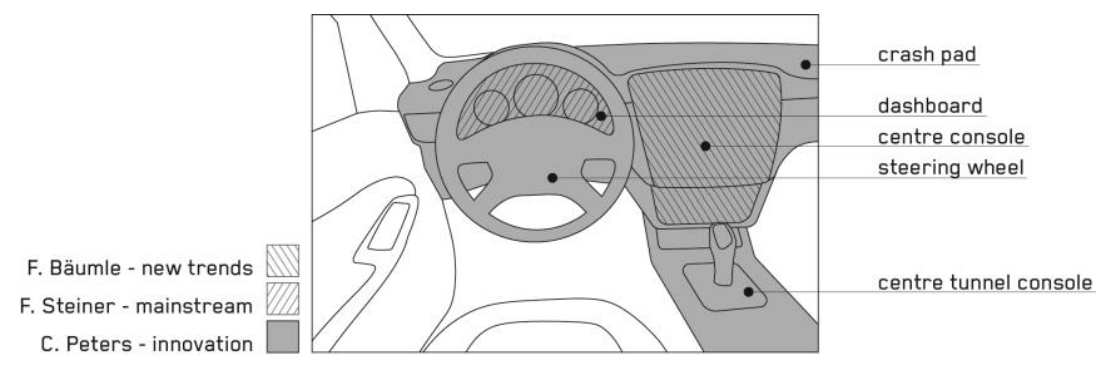

Figure 3. Key interaction points for each user group

\subsubsection{New trends - fostering multimodal mobility}

Since 2013, car sharing has experienced a large increase in customers, in particular as free-floating model (Bundesverband CarSharing, 2018). The attractiveness of free-floating lies particularly in the fact that the vehicles are station-independent and can be parked anywhere in the provider's business geographical area (Bogenberger et al., 2016). These one-way trips are interesting for users who want to be able to switch flexibly to other means of public transport (Kuhnimhof et al., 2012).

Being connected to others is a key aspect when using car sharing, therefore connected car technology is of specific relevance for future car sharing developments (Polchow, 2017). In this regard, Porter (2014) defines three types of connectivity: one-to-one, i.e. product to user; one-to-many, i.e. central system to many products; many-to-many, i.e. many products to many other products. Among car manufacturers addressing these trends, the MicroMAX concept car designed by Rinspeed uses the mobile app Swarm to allow users to share their locations, thus ensuring a cloud based mobility system (one-to-many). Rinspeed latest concept car Snap addresses autonomous driving and modularity in use to envision a system in which vehicle bodies (pods) are transported by skateboards to specific spots according to user needs (one-to-many and one-to-one). Mercedes-Benz started the private car sharing-platform Croove to help drivers share their own private car. The search for a suitable car and vehicle request is made via the corresponding app, and the platform is currently running in several German cities. Other examples of private car sharing system such as Ready to Share by Smart confirm the interest of car manufacturers in supporting multimodal mobility. Due to the growing importance of smartphone for connected car technology, companies like Bosch present platform-independent solutions (mySpin) that are designed to let drivers connect their smartphone easily to their car, and whose apps can be operated directly from the touchscreen of the centre console.

Car sharing has contributed to change mobility behaviour and the desire to own a vehicle has declined (Bogenberger et al., 2016). Chatterjee et al. (2018) prove that younger European generations have a significantly reduced interest in owning a car and in holding a driving licence. The number of 17- to 20 -year-olds holding a driving licence fell from $45 \%$ in 1992 to $29 \%$ in 2014, while $75 \%$ of 21 - to 29 year-olds still held a driving licence in 1992 and only 63\% in 2014; moreover, the number of trips per person also fell by 36\% between 1995 - 1999 and 2010 - 2014 (Chatterjee et al., 2018).

The mobility of this user group is of a multimodal kind (Kuhnimhof et al., 2012), as they use different types of transportation and switch between them depending on the situation. These car sharing users want to be intuitively connected to their environment and love to travel with a free choice of vehicles. Their main motivations are flexibility, connectivity and user-friendliness. The most important interaction point in car interior for them is the centre console, as this component is responsible for connecting the mobile phone to the vehicle, searching for traffic, and networking with other car sharing users.

\subsubsection{Mainstream - emphasizing the interlinkage between economy and sustainable driving}

Information on fuel consumption and efficient driving are communicated to the driver via the information cluster of the car dashboard. In this regard, Volkswagen offers an optional active info display for its vehicles to call up some information on the vehicle status and configure user settings. The driver profile selection offers the option to choose between classic, gear and speed, fuel consumption and range, efficiency, navigation, and driver assistance. The driving mode selection offers "comfort", "normal", "sport", "eco" and "individual" as options. Desired information on vehicle status to be displayed can be chosen via menu item: range, consumption, average consumption, driving time, oil temperature, speed, or average speed. Bosch relies on the networked navigation eHorizon to ensure homogeneous speed by avoiding unnecessary acceleration and deceleration during 
the journey. The cloud-based system uses real-time data on weather, accidents, and traffic jams to adapt braking and steering to the upcoming traffic situation.

In order to improve car-to-user communication, effective feedback should be customisable by the driver to adapt to his sustainable energy motivation (He et al., 2010). On this subject, the ecodriving system of Stillwater and Kurani (2013) offers a personalised interface, targets, and fuel price input; users get a feedback on fuel consumption/costs, electricity costs, and total costs.

This user group put great importance on a good price-performance ratio, reliability, and fuel efficiency. Therefore, the most important interaction point in car interior for these drivers is the dashboard, as it provides feedback on driving behaviour including the effects of environmental friendly driving on fuel economy.

\subsubsection{Innovation - highlighting new technological developments}

In the automotive industry, new technological innovations are initially implemented in low-volume production cars, as the advances are not mature enough for a large-scale production, and at a premium price tag, as they require high investments. Subsequently, technologies that have proven their worth are offered in lower price segments too, thus ultimately reaching the mass market. Tesla's development from the Roadster, via the model S, to the model 3, is an example of the top-down principle of technological development (Ramzy, 2016).

Due to this fashion in car development, observing present advances in the $\mathrm{F}$ segment is of specific relevance to forecast future interior features of E/J segment vehicles. The Mercedes S 500 PLUG-IN HYBRID offers a customisable interface style for the centre console, sound profiles as well as an individual configuration for steering, drive, chassis, and electronic stability control. Individual vehicle settings such as seat belt, acoustics from folding the doors, locking and panel heating can be selected as well via the centre console to suit individual requirements. The BMW 740e iPerformance drives with plug-in hybrid drivetrain. It features interior lighting that can be customised via the centre console display. The colour of the sky lounge as well as the perfume in the ventilation can be chosen. Comfort ventilation can be programmed in advance, and the driver is reminded acoustically when he leaves his mobile phone inside the car. Moreover, the BMW 740e iPerformance has a key fob containing an LCD touchscreen that can provide information on whether the windows and sunroof are opened or closed, the doors are locked or unlocked, fuel status, and service reminders (Newcomb, 2015).

Customers able to afford executive and sport cars are potential buyers of SUVs, and they consider high safety standards, modern engine technologies, product-related status symbol, driving pleasure, personalisable settings, and attractive design as key purchasing criteria (Weßner, 2017). According to Adam (2016), the car is still regarded as a status symbol by this customer group but it is losing importance as such, and it is increasingly becoming a lifestyle object; the key success factors of the premium automotive sector are subject to change and the emphasis is on the values of self-portrayal, individuality and co-creation.

The points of interaction that are interesting for this user typology are more widely distributed in the interior than for the other driver groups. The centre console is relevant for its symbolic value and affective motive of innovation. The dashboard, centre tunnel console, and steering wheel, are important due to their symbolic values and affective motives of driving pleasure. Finally, the crash pad plays an important role for its symbolic value and affective motive of quality, as users spontaneously tap on it for material evaluation (Montignies et al., 2010).

\subsection{Determination of environmentally friendly product personality}

Product personality can be defined as the ensemble of product aesthetics, product-driven associations, and consumer perceptions (Govers, 2004). The defined aesthetics evoke associations, which are referred to as the things the product reminds the observer of. The perceptions represent the reactions the product induces on the consumer, and they describe the way the product makes the user feel. In order to trigger the desired associations and perceptions in the user, design cues are of specific relevance. Design cues describe choices for design aspects that follow a specific aesthetic language to guide the design of a product (Karjalainen, 2003). Their definition involves chosen colours, shapes, patterns, textures, layouts, and materials.

In the field of automotive exterior design, Lee et al. (2015) previously examined product-driven associations of "green" design cues in Korea, and they provided information on user preferences of shape, texture, and colour: rounded, simple, and matte shapes can contribute to signalise green design 
to customers, while colours like white, green, and blue are associated with eco-friendliness. In eorder to further investigate environmentally friendly design cues, alternative fuel vehicles including hybrids and battery electric cars of German manufacturers are analysed. Variants for each car segments across different brands are considered, i.e. Mercedes for segment A, Volkswagen for segment C, and BMW for segment E, Table 1.

Table 1. Design cues for selected alternative fuel vehicles

\begin{tabular}{|l|c|l|l|}
\hline vehicle & car segment & design cues exterior & design cues interior \\
\hline $\begin{array}{l}\text { Smart eQ } \\
\text { fortwo }\end{array}$ & A & $\begin{array}{l}\text { colours: blue - model variant } \\
\text { logo, sharp-edged line under } \\
\text { front lip and tailgate, line around } \\
\text { rim, rear-view mirror covers }\end{array}$ & $\begin{array}{l}\text { colours: blue - frames around } \\
\text { air distribution vents and } \\
\text { instrument cluster }\end{array}$ \\
\hline VW e-Golf & $\mathrm{C}$ & $\begin{array}{l}\text { colours: blue - continuous } \\
\text { sharp-edged line under bonnet } \\
\text { continuing in headlights, model } \\
\text { logo on tailgate; } \\
\text { other: closed design of rims }\end{array}$ & $\begin{array}{l}\text { colours: blue - display, seam on } \\
\text { the steering wheel (crossed) and } \\
\text { gear stick (straight), stripes in } \\
\text { the grip area of the gear stick; } \\
\text { green - battery status }\end{array}$ \\
\hline $\begin{array}{l}\text { BMW 530e } \\
\text { iPerformance }\end{array}$ & E & $\begin{array}{l}\text { colours: blue - ring around brand } \\
\text { logo on wheels, closable radiator } \\
\text { grille ribs when switching on } \\
\text { electric motor }\end{array}$ & $\begin{array}{l}\text { colours: blue - straight glowing } \\
\text { line under crash pad continuing } \\
\text { on door panels, information } \\
\text { cluster elements }\end{array}$ \\
\hline
\end{tabular}

\subsubsection{Design cues of alternative fuel vehicles}

According to our analysis, specific design cues implemented by German car makers to represent a vehicle that runs on a fuel other than traditional petroleum fuels, e.g. battery electric vehicles, or at least does not involve solely petroleum to power the engine, e.g. hybrid electric cars, can be described. The study reveals that, among yellow, green, and blue used as accent colours to visually represent alternative fuel vehicles both in car exterior and interior, the latter one clearly prevails. In particular, blue lines running across the exterior (e.g. under the bonnet continuing in the headlights), or through components of the interior (e.g. under the crash pad continuing on the door panels), are of frequent use. However, rather than round, simple and matt elements, as identified by Lee et al. (2015), the design cues of the examined vehicles feature sharp-edged shapes and glowing elements.

The design cues appear to be more prominent in the exterior than in the interior. In car exterior, design cues are mostly located at the doors, under the bonnet, or they underline the logos of the brand or the specific model variant. Closed design of rims and radiator grills, which are implemented to lower the drag coefficient and improve fuel efficiency, also affect the appearance of these cars.

In car interior, coloured logos, glowing stripes, and additional styling elements are currently used to show the peculiarity of the vehicles. In particular, design cues for alternative fuel vehicles are applied primarily on the crash pad (e.g. Smart eQ fortwo, VW e-up!, 530e iPerformance) and dashboard (VW e-Golf, VW Golf GTE, BMW i3, Mini Cooper S E Countryman Plug-in-Hybrid), where feedback to eco-friendly driving mode is located. Other components such as the centre tunnel console (e.g. gear stick of the VW Golf GTE), steering wheel and seats (e.g. BMW i3), and door panels (e.g. BMW i3, $530 \mathrm{e}$ iPerformance) are considered in some car interiors.

\subsubsection{Material as medium of the environmentally friendly product personality}

The choice of material plays an important role for the creation of a desired product personality (Ashby and Johnson, 2002). In this regard, the selection of materials that are perceived as sustainable can play an important role in the definition of a multisensory experience in vehicle interior, since passengers can vision, touch, and smell them. However, while $83 \%$ of the respondents of a German study specifically advocated the use of renewable materials in the non-visible area of automotive interiors (Hetterich et al., 2012), no research has provided evidence for customer willingness to actually see and feel renewable materials in car vehicle.

Among present attempts of car manufacturers to bring out the sustainable character of the vehicle by making the material visible to the passengers, BMW focused on door panelling and on an instrument panel cover to implement visual natural fibres in the i3 car interior. The alternative fuel car displays a 
kenaf natural fibre non-woven fabric that is combined with fibres made of polypropylene. As the analysis reported in this subsection highlighted commonly shared design cues of alternative fuel vehicles, understanding if these vehicles are perceived as environmental friendly is key.

On this subject, Landau et al. (2013) provided the word "sustainability" to testers for the description of specific materials expected to evoke "electromobility" characteristics, i.e. material design cues for alternative fuel vehicles. Interestingly, $46 \%$ of the participants involved in this study associated green artificial turf with the word "sustainability". Consequently, users associate sustainability with materials that are not necessarily environmental friendly.

\section{IMPLICATIONS}

Car interior designers are confronted with new challenges concerning the combination of user-friendly interfaces with an environmentally friendly product personality. In this paper German key customers were defined through personas according to socio-economic characteristics collected from literature. Moreover, present design cues implemented by German car manufacturers to create an environmentally friendly product personality were explored.

The creation of three personas aimed at defining key interaction points for three German car user groups with pro-environmental behaviour. Summing up, the most important interior car components for user interaction are centre console, centre tunnel console, crash pad, dashboard, and steering wheel.

The first user group, i.e. Generation $Z$, is interested in multimodal mobility and has pro-environmental behaviour, as it does not own a car at all. The second focus group, i.e. Generation Y, focusses on good price-performance-ratio and proves its pro-environmental behaviour through fuel-efficient driving. The third group, i.e. Generation X, is influenced by the symbolic values and affective motives linked to driving a car, and it shows its pro-environmental behaviour by purchasing the latest clean technologies available on the market. Consequently, the three displayed pro-environmental behaviours are linked with their respective socio-economic background. The driving and purchasing choices of the first two groups are driven by economic reasons, while the third group is purchasing cars to reflect its lifestyle and social status.

The analysis of German battery electric- and hybrid vehicles highlighted commonly shared design cues of alternative fuel vehicles, in particular blue coloured sharp-edged shapes and glowing elements play an important role in the visual representation of both car exterior and interior. As the presented analysis on German cars is in contrast with past research on product-driven associations and consumer perceptions of green design cues carried out in Korea, future studies should address cultural aspects related to this topic. Moreover, the low number of identified design cues of alternative fuel vehicles shows potential for car interior designers to enhance it. This could lead to an increased perception of the environmentally friendly product personality, especially by integrating them in the aforementioned key interaction points. In order to implement design cues to design a material communicating environmental-friendliness, future work should address both buyers and drivers to study possible trade-offs between associations of alternative fuel vehicles and perception of sustainability.

\section{REFERENCES}

Adam, N. (2016), "Key Success Factors for Automotive Premium Brands in Answer to the Change of Luxury and Societal Changes", in International Marketing Trends Conference Proceedings, Venice.

Arbeitsgemeinschaft Verbrauchs- und Medienanalyse (2017), VuMA Touchpoints 2017. Arbeitsgemeinschaft Verbrauchs- und Medienanalyse (Ed.), Frankfurt a. M.

Ashby, M.F. and Johnson, K. (2002), Materials and design: the art and science of material selection in product design, Butterworth-Heinemann, Oxford.

BMW, DLR, DB Rent, Landeshauptstadt München, Universität der Bundeswehr München and Senatsverwaltung für Stadtentwicklung und Umwelt Berlin (2016), Wirkung von E-Car Sharing Systemen auf Mobilität und Umwelt in urbanen Räumen (WiMobil), available at: https://www.erneuerbarmobil.de/sites/default/files/2016-10/Abschlussbericht_WiMobil.pdf (accessed 6 December 2018).

Bogenberger, K., Müller, J., Weikl, S. and Schmöller, S. (2016), "Entwicklung und Nutzungsstruktur von Carsharing-Systemen in Deutschland", in Wappelhorst, S., Jacoby, C. and Akademie für Raumforschung und Landesplanung -Leibniz-Forum für Raumwissenschaften (Eds.), Potenziale neuer Mobilitätsformen und -technologien für eine nachhaltige Raumentwicklung., Verl. d. ARL, Hannover. 
Bolton, R.N., Parasuraman, A., Hoefnagels, A., Migchels, N., Kabadayi, S., Gruber, T., Komarova Loureiro, Y. and Solnet, D. (2013), "Understanding Generation Y and their use of social media: a review and research agenda", Journal of Service Management, Vol. 24 No. 3, pp. 245-267. http://doi.org/10.1108/09564231311326987.

Bundesverband CarSharing (2018), Aktuelle Zahlen und Daten zum CarSharing in Deutschland. Bundesverband CarSharing (Ed.), available at: https://carsharing.de/alles-ueber-carsharing/carsharing-zahlen/aktuellezahlen-daten-zum-carsharing-deutschland (accessed 20 November 2018).

Chatterjee, K., Goodwin, P., Schwanen, T., Clark, B., Jain, J., Malia, S., Middleton, J., Plyushteva, A., Ricci, M. and Santos, G. and Stokes, G. (2018), Young People's Travel - What's Changed and Why? Review and Analysis: Report to Department for Transport, UWE Bristol (Ed.), Bristol, UK.

Choo, S. and Mokhtarian, P.L. (2004), "What type of vehicle do people drive? The role of attitude and lifestyle in influencing vehicle type choice", Transportation Research Part A: Policy and Practice, Vol. 38 No. 3 , pp. 201-222. http://doi.org/10.1016/j.tra.2003.10.005.

Commission of the European Communities (1999), Regulation (EEC) No 4064/89 Merger Procedure, Office for Official Publications of the European Communities L-2985 Luxembourg (Ed.), Brussel, Belgium.

Ford (2016), Ford-Studie erklärt anhaltende Beliebtheit von SUVs, Ford (Ed.), available at: https://media.ford.com/content/fordmedia/feu/de/de/news/2016/05/12/ford-studie-erklaert-anhaltendebeliebtheit-von-suvs.html (accessed 19 November 2018).

Govers, P.C.M. (2004), "Product Personality", Dissertation, Delft University of Technology, Delft, 15 June.

Govers, P.C.M. and Schoormans, J.P. (2005), "Product personality and its influence on consumer preference", Journal of Consumer Marketing, Vol. 22 No. 4, pp. 189-197.

He, H.A., Greenberg, S. and Huang, E.M. (2010), "One size does not fit all: Applying the Transtheoretical Model to Energy Feedback Technology Design”, in Mynatt, E., Schoner, D., Fitzpatrick, G., Hudson, S., Edwards, K. and Rodden, T. (Eds.), Proceedings of the SIGCHI conference on human factors in computing systems, ACM, pp. 927-936. http://doi.org/10.1145/1753326.1753464.

Hekkert, P. and Dijk, M. (2001), "Designing from context: Foundations and applications if the ViP approach", in Loyd, P. and Christiaans, H. (Eds.), Designing in Context: Proceedings of DTRS 5, Delft University Press.

Hetterich, J., Bonnemeier, S., Pritzke, M. and Georgiadis, A. (2012), "Ecological sustainability - a customer requirement? Evidence from the automotive industry", Journal of Environmental Planning and Management, Vol. 55 No. 9, pp. 1111-1133. http://doi.org/10.1080/09640568.2011.636578.

International Council on Clean Transportation Europe (2017), European Vehicle Market Statistics 2017/2018, Mock, P. (Ed.), Berlin.

Kambeck, R., Kasten, T. and Siemers, L.-H.R. (2009), Zur Einkommenssituation der privaten Haushalte in Deutschland: Endbericht, Projekt im Auftrag von AWD, Hannover. Rheinisch-Westfälisches Institut für Wirtschaftsforschung Essen (Ed.), Essen.

Karjalainen, T.M. (2003), "Strategic brand identity and symbolic design cues", in 6th Asian Design Conference, Tsukuba, Japan, pp. 1-13.

Kopp, J.P. (2015), "GPS-gestützte Evaluation des Mobilitätsverhaltens von free-floating CarSharing-Nutzern", Doctoral Thesis, ETH Zurich, Zurich, p. 2015.

Köster, U. and Pütz, E. (2018), Zahlen and Fakten 2017: Ausgabe 2018, Wirtschaftsgesellschaft des Kraftfahrzeuggewerbes mbH (Ed.), Bonn.

Kuhnimhof, T., Buehler, R., Wirtz, M. and Kalinowska, D. (2012), "Travel trends among young adults in Germany: increasing multimodality and declining car use for men”, Journal of Transport Geography, Vol. 24, pp. 443-450. http://doi.org/10.1016/j.jtrangeo.2012.04.018.

Landau, M., Koerber, M. and Loehmann, S. (2013), "Towards a Multisensory Representation of Electromobility Characteristics", in Terken, J., Riener, A., Schroeter, R. and Osswald, S. (Eds.), Automotive User Interfaces and Interactive Vehicular Applications, Adjuct Proceedings, Eindhoven University of Technology, Eindhoven, pp. 17-20.

Lee, J., Jung, B. and Chu, W. (2015), "Signaling Environmental Altruism through Design: The Role of Green Cue Prominence in Hybrid Cars”, International Journal of Design, Vol. 9 No. 2, pp. 79-91.

Loose, W. (2010), Aktueller Stand des Car-Sharing in Europa, Endbericht D 2.4 Arbeitspaket, momo Carsharing-More options for energy efficient mobility through Car-Sharing, Bundesverband CarSharing e. V. (Ed.), Freiburg.

Luccarelli, M. (2017), "Material Perception in Alternative Fuel Car Interiors. Increasing Marketability through Green Design Cues", in Proceedings of the 30th International Electric Vehicle Symposium, EVS30, Stuttgart, Germany.

Mangelsdorf, M. (2015), Von Babyboomer bis Generation Z: Der richtige Umgang mit unterschiedlichen Generationen im Unternehmen, Whitebooks, Gabal, Offenbach.

Merk, N. (2018), DriveNow Kunden, telephone interview, Reutlingen, München.

Miaskiewicz, T. and Kozar, K.A. (2011), "Personas and user-centered design: How can personas benefit product design processes?”, Design Studies, Vol. 32 No. 5, pp. 417-430.

http://doi.org/10.1016/j.destud.2011.03.003. 
Montignies, F., Nosulenko, V. and Parizet, E. (2010), "Empirical identification of perceptual criteria for customer-centred design. Focus on the sound of tapping on the dashboard when exploring a car", International Journal of Industrial Ergonomics, Vol. 40 No. 5, pp. 592-603. http://doi.org/10.1016/j.ergon.2010.04.004.

Naderer, G. and Balzer, E. (2007), Qualitative Marktforschung in Theorie und Praxis, Vol. 1. Aufl., Gabler Verlag, Wiesbaden.

Naumann, L. (2016), “Im Fokus: Attraktivität von Carsharing-Angeboten”, Horizont, Vol. 26 February, p. 26, available at: https://www.horizont.net/media/media/13/2015-009_HOR-

Report_Zukunft_der_Mobilitaet.pdf-128140.pdf (accessed 19 November 2018).

Newcomb, D. (2015), Six New Innovations That Set The 2016 BMW 7 Series Apart, Forbes (Ed.), available at: https://www.forbes.com/sites/dougnewcomb/2015/09/04/six-new-innovations-that-set-the-2016-bmw-7series-apart/ (accessed 19 November 2018).

Polchow, Y. (2017), Carit, available at: https://www.car-it.com/iaa-sonderedition-2017 (accessed 19 November 2018).

Porter, M.E. and Heppelmann, J.E. (2014), "How Smart, Connected Products Are Transforming Competition", Harvard Business Review, November 2014.

Ramzy, A. (2016), Tesla Model 3 Orders Surge Even Before Its Unveiling, New York Times (Ed.), available at: https://www.nytimes.com/2016/04/02/business/international/tesla-model-3.html.

Schreier, H., Becker, U. and Heller, J. (2015), Evaluation CarSharing (EVA-CS) Landeshauptstadt München, Endbericht. teamred (Ed.), Berlin.

Shaheen, S.A. and Cohen, A.P. (2013), "Carsharing and Personal Vehicle Services: Worldwide Market Developments and Emerging Trends”, International Journal of Sustainable Transportation, Vol. 7 No. 1 , pp. 5-34. http://doi.org/10.1080/15568318.2012.660103.

Statista (2016), Welche dieser Funktionen wünschen Sie sich für Ihr Auto?, Statista (Ed.), available at: https:/de.statista.com/statistik/daten/studie/633897/umfrage/funktionen-die-sich-autofahrer-indeutschland-fuer-ihr-auto-wuenschen/ (accessed 19 November 2018).

Statista (2017a), Für welchen Fahrzeugtyp würden Sie sich beim nächsten Autokauf entscheiden?, Statista (Ed.), available at: https://de.statista.com/statistik/daten/studie/715205/umfrage/umfrage-zum-fahrzeugtyp-beizukuenftigem-pkw-kauf-in-deutschland-nach-geschlecht/ (accessed 19 November 2018).

Statista (2017b), Planen Sie in den kommenden 2 Jahren die Anschaffung eines neuen Pkw - egal ob dienstlich oder privat?, Statista (Ed.), available at: https://de.statista.com/statistik/daten/studie/715259/umfrage/umfrage-zur-planung-der-neuanschaffungeines-pkw-in-deutschland/ (accessed 19 November 2018).

Statista (2017c), Welche Fahrzeugmerkmale bei der Kaufentscheidung für Ihr Fahrzeug sind Ihnen besonders wichtig?, Statista (Ed.), available at: https://de.statista.com/statistik/daten/studie/716905/umfrage/umfragezu-den-wichtigsten-fahrzeugmerkmalen-beim-autokauf-in-deutschland/ (accessed 19 November 2018).

Statistisches Bundesamt (Destatis) (2018), Durchschnittliche Bruttomonatsverdienste, Statistisches Bundesamt (Destatis) (Ed.), available at:

https://www.destatis.de/DE/ZahlenFakten/GesamtwirtschaftUmwelt/VerdiensteArbeitskosten/VerdiensteV erdienstunterschiede/Tabellen/Bruttomonatsverdienste.html (accessed 19 November 2018).

Steg, L. (2005), "Car use: lust and must. Instrumental, symbolic and affective motives for car use", Transportation Research Part A: Policy and Practice, Vol. 39 No. 2-3, pp. 147-162. http://doi.org/10.1016/j.tra.2004.07.001.

Stillwater, T. and Kurani, K.S. (2013), "Drivers discuss ecodriving feedback: Goal setting, framing, and anchoring motivate new behaviors", Transportation Research Part F: Traffic Psychology and Behaviour, Vol. 19, pp. 85-96. http://doi.org/10.1016/j.trf.2013.03.007.

Turner, A. (2015), “Generation Z: Technology and Social Interest”, The Journal of Individual Psychology, Vol. 71 No. 2, pp. 103-113. http://doi.org/10.1353/jip.2015.0021.

Weßner, K. (2017), Hohe Kundenloyalität und weiteres Wachstum: puls Studie zum Siegeszug der SUVs, puls Marktforschung GmbH, Nürnberg.

Wever, R., van Kuijk, J. and Boks, C. (2008), "User-centred design for sustainable behaviour", International journal of sustainable engineering, Vol. 1 No. 1, pp. 9-20. http://doi.org/10.1080/19397030802166205.

\section{ACKNOWLEDGEMENTS}

The authors acknowledge the financial support of the European Regional Development Fund (ERDF) and the German Ministry of Science, Research and Art of the Federal State Baden-Württemberg for the Project InBiO (FEIH_KMU_1098885). 